\title{
Diversity and Guilds of Ants in Different Land-Use Systems in Rio de Janeiro State, Brazil
}

\author{
Laiz da Cunha Messias Honório Apolinário ${ }^{1}$ (D) Ângela Alves de Almeida ${ }^{1}$ (D), \\ Jarbas Marçal Queiroz ${ }^{2}$ (D), André Barbosa $\operatorname{Vargas}^{3}$ (D) Fábio Souto Almeida ${ }^{1}$ (D) \\ ${ }^{1}$ Universidade Federal Rural do Rio de Janeiro (UFRRJ), Três Rios, RJ, Brasil \\ ${ }^{2}$ Universidade Federal Rural do Rio de Janeiro (UFRRJ), Seropédica, RJ, Brasil \\ ${ }^{3}$ Centro Universitário de Volta Redonda (UniFOA), Volta Redonda, RJ, Brasil
}

\begin{abstract}
This study aimed to evaluate the ant fauna in three different land-use systems: pasture, eucalyptus plantation and secondary forest, in southeastern Brazil. The ant fauna was collected with standardized pitfall traps. Forty-seven ant species were collected, belonging to 24 genera and six subfamilies. The total ant species richness was significantly higher in secondary forest (29 species) and eucalyptus plantation (25 species) when compared to the pasture (17 species), with no significant difference between the secondary forest and eucalyptus plantation. The species composition differed significantly between the three land-use systems. The frequency distributions of ant guilds in eucalyptus plantation and secondary forest differed significantly from the frequency in the pasture. The results demonstrated the importance of natural forests for the conservation of biological diversity of the Atlantic Forest, but they also indicated that eucalyptus plantations, with native understory plants, can harbor considerable ant diversity.
\end{abstract}

Keywords: biodiversity, Corymbia, Formicidae, seasonal forest. 


\section{INTRODUCTION AND OBJECTIVES}

The Atlantic Forest is considered one of the most important biomes in the world due to its high diversity and endemism of plants and animals (Joly et al., 2014). Hence, its protection is especially relevant for the conservation of biodiversity (Myers et al., 2000). In the past centuries, indiscriminate exploitations of natural resources by different land-use regimes and successive economic cycles changed the natural landscape and put at risk the biome's biological diversity (Ribeiro et al., 2011; Silvério Neto et al., 2015).

The state of Rio de Janeiro, southeastern Brazil, has some remaining Atlantic Forest areas distributed in small and isolated fragments (Silvério Neto et al., 2015). Semi-deciduous seasonal forests figure among the vegetation types of this biome that were most reduced and degraded by human activities, and thus, their biodiversity is severely threatened (Brasil, 2007; Ribeiro et al., 2011). Several areas naturally covered by semi-deciduous seasonal forests were converted to urban areas, pastures, commercial forests, and agroecosystems (Brasil, 2007; Ribeiro et al., 2011), which caused habitat loss and simplification (Martins et al., 2011). It is worth mentioning that a reduction in environmental heterogeneity decreases the diversity of the ecological niches, and, consequently, biodiversity loss (Braga et al., 2010; Estrada et al., 2014; Oliveira et al., 2014). However, the replacement of natural ecosystems with other land-use systems does not mean that the environment becomes completely inhospitable to biodiversity (DaRocha et al., 2016; Santos et al., 2015), since it is possible to conciliate agriculture, livestock farming, and forest production with the conservation of at least part of the biodiversity (Dias et al., 2008).

Therefore, assessing the contribution of environments with different land-use systems for biodiversity conservation is important. In terrestrial ecosystems, the ant fauna deserves special attention due to its ecological importance, broad geographic distribution, high species richness, abundance and biomass, collection easiness, and sensitivity to environmental change (Agosti et al., 2000; Gomes et al., 2012; Ribas et al., 2012). Anthropic actions influence the ant fauna because they change biotic and abiotic factors in ecosystems, such as air temperature, leaf litter abundance and plant diversity (Almeida et al., 2007; Estrada et al., 2014; Gomes et al., 2013). Accordingly, ant communities are frequently used as bioindicators of biodiversity and environmental quality in terrestrial ecosystems (Braga et al., 2010; Pereira et al., 2007; Ribas et al., 2012). In this sense, studies indicate that ant species richness and diversity decrease with the reduction of the structural complexity of ecosystems (Gomes et al., 2013; Martins et al., 2011).

In addition to assessing the taxonomic diversity, it is important to analyze the composition of ant guilds, as they are related to different ecological functions (Boscardin et al., 2014; Macedo et al., 2011). Ant guilds are influenced by environmental impacts, which can compromise their functions in ecosystems and the environmental quality (Boscardin et al., 2014; Kwon et al., 2014; Macedo et al., 2011); however, few studies have evaluated ant guilds in different land-use systems, including in the Atlantic Forest dominium.

The objective of the present study was to compare the ant fauna and their guilds in different land-use systems in the Atlantic Forest. Hence, the following hypotheses were tested: 1) the land-use system influences the richness and diversity of ants, being smaller in habitats with lower environmental heterogeneity; 2) the land-use system affects the composition and guilds of the ant fauna; and 3) air temperature and leaf litter are important environmental variables in the ant fauna structuring.

\section{MATERIALS AND METHODS}

\subsection{Study area}

Our study was carried out in the municipality of Sapucaia, state of Rio de Janeiro, Brazil, which has an area of $541.181 \mathrm{~km}^{2}$ and an altitude of $221 \mathrm{~m}$ a.s.l (IBGE, 2016). The climate is predominantly semi-humid hot and sub-hot (IBGE, 2002). Winter is the season with the lowest rainfall and the mean annual rainfall is 1,181 mm (IBGE, 2002; Inea, 2014). The average temperature varies from $20^{\circ} \mathrm{C}$ to $24^{\circ} \mathrm{C}$ (Napoleão, 2011). Inserted within the Atlantic Forest, Sapucaia shows urban areas, crop areas, eucalyptus plantations, pastures, and semi-deciduous seasonal forest fragments (IBGE, 2016) and the forest cover 
of the region is mostly composed of small fragments in different stages of regeneration (Silvério Neto et al., 2015).

We chose three areas for the study: a fragment of a second-growth forest with an area of 8.3 ha ( $22^{\circ} 3^{\prime} 29.75^{\prime \prime} \mathrm{S}$ and $\left.42^{\circ} 59^{\prime} 2.28^{\prime \prime} \mathrm{W}\right)$, a bovine pasture with 6.9 ha $\left(22^{\circ} 3^{\prime} 44.39^{\prime \prime} \mathrm{S}\right.$ and $\left.42^{\circ} 59^{\prime} 5.56^{\prime \prime} \mathrm{W}\right)$, and a plantation of lemon eucalyptus (Corymbia citriodora (Hook)) with 9.6 ha $\left(22^{\circ} 3^{\prime} 52.28^{\prime \prime} \mathrm{S}\right.$ and $42^{\circ} 58^{\prime} 54.60^{\prime \prime} \mathrm{W}$ ). According to the characteristics predicted in the Conama Resolution (1994), the secondary forest was at an intermediate regeneration stage. Its physiognomy was dominated by trees and shrubs, with average circumference at the breast height $(\mathrm{CBH})$ of $31 \mathrm{~cm}$, average height of $4.95 \mathrm{~m}$, approximately 20 years old, with predomination of woody lianas. The bovine pasture was covered by grasses of the species Brachiaria brizantha (Hochst ex A. Rich) (palisade grass), with the presence of shrubs, with $\mathrm{CBH}$ below $0.15 \mathrm{~cm}$, such as the species Baccharis dracunculifolia DC and Blainvillea sp., as well as a few trees. The eucalyptus plantation was approximately 10 years old, and part of the planted trees had already been cut down and harvested. The eucalyptus trees showed an average height of $11.80 \mathrm{~m}$ and an average $\mathrm{CBH}$ of $72 \mathrm{~cm}$. We observed that several areas of the eucalyptus plantation showed a developed understory with native species and a remarkable leaf litter layer.

\subsection{Sampling}

Ant collection was carried out in May 2015 in four $300-\mathrm{m}^{2}$ plots $(30 \mathrm{~m} \times 10 \mathrm{~m})$ at $30 \mathrm{~m}$ away from one another, in the center of each land-use system. Six pitfall traps containing $100 \mathrm{ml}$ of alcohol $70 \%$ were set up inside the perimeter of each plot at $10-\mathrm{m}$ intervals, which remained active for $48 \mathrm{~h}$. After this period, the contents of traps were removed and placed in labeled polyethylene containers with alcohol $70 \%$. The containers were taken to the laboratory, where the material was sorted. Ants were dry-fixed and identified to the genus level with the taxonomic key proposed by Baccaro et al. (2015) and to the species with specific keys for the species of each genus and comparisons with previously identified individuals. Our reference collection is the Coleção Entomológica Costa Lima at Universidade Federal Rural do Rio de Janeiro (Agosti et al., 2000).
The classification of ants in guilds followed Delabie et al. (2000), Silvestre \& Silva (2001), Groc et al. (2014), and Pereira et al. (2016). The following guilds were used: (1) arboreal omnivorous; (2) leafcutters; (3) fungus-growers (except leafcutter); (4) soil or litter dominants; (5) soil or litter dominant true omnivorous; (6) litter omnivores and scavengers; (7) soil cryptic predators; and (8) litter generalist predators. For the ants that were not identified to the species level, the classification was based on information available for the genus (Delabie et al., 2000; Groc et al., 2014; Silvestre \& Silva, 2001). We chose to allocate the leafcutters ants in a different guild from other fungusgrowers, due to the significant differences in behavior and resource use (Silvestre \& Silva, 2001).

Air temperature was measured with a digital thermometer placed beside each pitfall. Soil cover by leaf litter was also obtained close to each pitfall, with a $2,500-\mathrm{cm}^{2}$ gridded square, with $100 \mathrm{~cm}^{2}$ divisions placed on the soil to estimate the percentage of the area of the square covered by leaf litter.

\subsection{Data analysis}

For data analysis, we built species accumulation curves using the Mao Tau method, with the data obtained in each pitfall trap to analyze the total ant species richness in different land-use systems. The total ant species richness was significantly different between land-use systems when the $95 \%$ confidence intervals did not overlap (Gomes et al., 2013). To test the normality of the data we used the Lilliefors test. We used the Ancova with the data of each plot to compare the average richness and the average diversity (Shannon index, using natural log - ln) (dependent variables) in land-use systems (factor) and assess the effect of air temperature and leaf litter cover (covariates), followed by Tukey tests. The arcsine square root transformation was utilized for leaf litter cover data normalization. We also obtained the estimated species richness (Chao 2). We assessed the similarity of the ant fauna among land-use systems with the non-metric multidimensional scaling (NMDS) using the Jaccard similarity index and Anosim to determine significance (e.g. Gomes et al., 2013). The temperature and litter leaf cover were incorporated into the analysis, yielding vectors representing the correlation between these environmental variables and the NMDS scores in the 
PAST program (version 2.17) (Hammer et al., 2001). The chi-square test $\left(\chi^{2}\right)$ was used to compare frequency of ant species richness per guilds between land-use systems (e.g. Pereira et al., 2016).

\section{RESULTS}

We collected 47 ant species of 24 genera and six subfamilies (Table 1). Myrmicinae was the subfamily with the largest number of species (26), followed by Formicinae (six). Pheidole was the genus with the largest number of species (six), followed by Camponotus, Ectatomma, and Solenopsis, all with four species.

The secondary forest showed the highest values of richness, diversity, evenness and estimated richness, followed by the eucalyptus plantation, and pasture (Table 2). The cumulative species richness was significantly higher on the secondary forest and eucalyptus plantation than in the pasture (Figure 1). However, there was no significant difference between the secondary forest and eucalyptus plantation. We observed that the species accumulation curves did not reach the asymptote.

The type of land-use influenced the ant species richness (Ancova; $\mathrm{F}_{2,12}=5.52 ; p=0.04$; Figure 2), in contrast to temperature (Ancova; $\mathrm{F}_{1,12}=2.59 ; p=0.15$; Figure 3 ) and leaf litter (Ancova; $\mathrm{F}_{1,12}=0.80 ; p=0.40$; Figure 3$)$. Likewise, the land-use system affected species diversity (Ancova; $\mathrm{F}_{2,12}=7.02 ; p=0.02$; Figure 4), unlike temperature (Ancova; $\mathrm{F}_{1,12}=2.84 ; p=0.14$; Figure 5) and leaf litter cover (Ancova; $\mathrm{F}_{1,12}=0.44$; $p=0.53$; Figure 5). The average richness and diversity were significantly higher on the secondary forest and eucalyptus plantation compared to pasture.

Table 1. Frequency (number of pitfall traps) and guilds of ant species in different land-use systems in the municipality of Sapucaia, Rio de Janeiro, Brazil.

\section{Subfamilies/Species}

\section{Dolichoderinae}

\begin{tabular}{|c|c|c|c|c|}
\hline Dorymyrmex sp.1 & 1 & - & - & LOS \\
\hline Linepithema sp.1 & - & 5 & 4 & LOS \\
\hline \multicolumn{5}{|l|}{ Ectatomminae } \\
\hline Ectatomma edentatum Roger, 1863 & 19 & 4 & 1 & SLD \\
\hline Ectatomma brunneum F. Smith, 1858 & 1 & 12 & - & SLD \\
\hline Ectatomma permagnum Forel, 1908 & - & 2 & 11 & SLD \\
\hline Ectatomma tuberculatum Olivier, 1792 & - & - & 4 & SLD \\
\hline Gnamptogenys sp.1 & 1 & - & - & LGP \\
\hline \multicolumn{5}{|l|}{ Formicinae } \\
\hline Brachymyrmex sp.1 & 9 & 9 & - & SLO \\
\hline Brachymyrmex sp.2 & - & 1 & 3 & SLO \\
\hline Camponotus rufipes Fabricius, 1775 & 17 & 2 & - & SLO \\
\hline Camponotus sp.1 & - & 3 & 2 & SLO \\
\hline Camponotus sp. 2 & - & - & 1 & SLO \\
\hline Camponotus sp.3 & - & - & 1 & SLO \\
\hline Nylanderia sp.1 & - & 1 & - & SLO \\
\hline \multicolumn{5}{|l|}{ Myrmicinae } \\
\hline Acromyrmex sp.1 & 1 & - & - & $\mathrm{LC}$ \\
\hline Atta sexdens rubropilosa Forel, 1908 & 2 & 14 & 7 & LC \\
\hline Cephalotes pusillus (Klug, 1824) & 1 & - & - & $\mathrm{AO}$ \\
\hline Crematogaster sp. 1 & 2 & - & - & $\mathrm{AO}$ \\
\hline Cyphomyrmex sp.1 & 1 & - & - & FG \\
\hline
\end{tabular}


Table 1. Continued...

\begin{tabular}{|c|c|c|c|c|}
\hline \multirow{2}{*}{ Subfamilies/Species } & \multicolumn{3}{|c|}{ Land-use systems } & \multirow{2}{*}{ Guilds } \\
\hline & Pasture & Eucalyptus plantation & Secondary forest & \\
\hline \multicolumn{5}{|l|}{ Myrmicinae } \\
\hline Cyphomyrmex sp.2 & - & 1 & - & FG \\
\hline Mycocepurus goeldii (Forel, 1893) & - & 2 & - & FG \\
\hline Mycocepurus smithii (Forel, 1893) & - & 2 & 4 & FG \\
\hline Pheidole prox. fallax Mayr, 1870 & 1 & 10 & 1 & LOS \\
\hline Pheidole radoszkowskii Mayr, 1884 & - & 7 & - & LOS \\
\hline Pheidole sp.1 & 7 & 4 & 9 & LOS \\
\hline Pheidole sp.2 & 2 & 12 & 8 & LOS \\
\hline Pheidole sp.3 & - & 7 & 1 & LOS \\
\hline Pheidole sp.4 & - & - & 2 & LOS \\
\hline Sericomyrmex sp.1 & - & - & 1 & FG \\
\hline Sericomyrmex sp.2 & - & - & 3 & FG \\
\hline Solenopsis sp.1 & 1 & - & - & LOS \\
\hline Solenopsis sp.2 & - & 1 & - & LOS \\
\hline Solenopsis sp.3 & - & 1 & 2 & LOS \\
\hline Solenopsis sp.4 & - & - & 4 & LOS \\
\hline Trachymyrmex sp.1 & - & - & 1 & FG \\
\hline Trachymyrmex sp.2 & - & - & 1 & FG \\
\hline Tranopelta gilva Mayr, 1866 & - & - & 1 & SCP \\
\hline Wasmannia auropunctata (Roger, 1863) & 10 & 3 & 1 & SLO \\
\hline Wasmannia sp.1 & - & 1 & 1 & SLO \\
\hline Wasmannia sp.2 & - & - & 2 & SLO \\
\hline \multicolumn{5}{|l|}{ Ponerinae } \\
\hline Anochetus sp.1 & 1 & - & - & LGP \\
\hline Neoponera verenae (Forel, 1922) & - & 1 & - & LGP \\
\hline Odontomachus chelifer Latreille, 1802 & - & 1 & 13 & SLD \\
\hline Odontomachus sp.1 & - & - & 2 & SLD \\
\hline Pachycondyla lenis Kempf, 1961 & - & - & 3 & LGP \\
\hline Pachycondyla striata Smith, F., 1858 & - & - & 3 & LGP \\
\hline \multicolumn{5}{|l|}{ Pseudomyrmecinae } \\
\hline Pseudomyrmex termitarius Smith, F., 1855 & - & 1 & - & LOS \\
\hline
\end{tabular}

AO: arboreal omnivorous; LC: leafcutters; FG: fungus-growers; SLD: soil or litter dominants; SLO: soil or litter dominant true omnivorous; LOS: litter omnivores and scavengers; SCP: soil cryptic predators; LGP: litter generalist predators.

Table 2. Ant species richness, diversity of Shannon ( $\mathrm{H}^{\prime}$ ), equitability and estimated richness (Chao 2 ) in different land-use systems in the municipality of Sapucaia, Rio de Janeiro, Brazil.

\begin{tabular}{lccc} 
& \multicolumn{3}{c}{ Land-use systems } \\
\cline { 2 - 4 } & Pasture & Eucalyptus plantation & Secondary forest \\
\hline Richness & 17 & 25 & 29 \\
Diversity (H') & 2.21 & 2.82 & 3.01 \\
Equitability & 0.53 & 0.67 & 0.70 \\
Estimated richness (Chao 2) & 25.63 & 31.90 & 37.78 \\
\hline
\end{tabular}




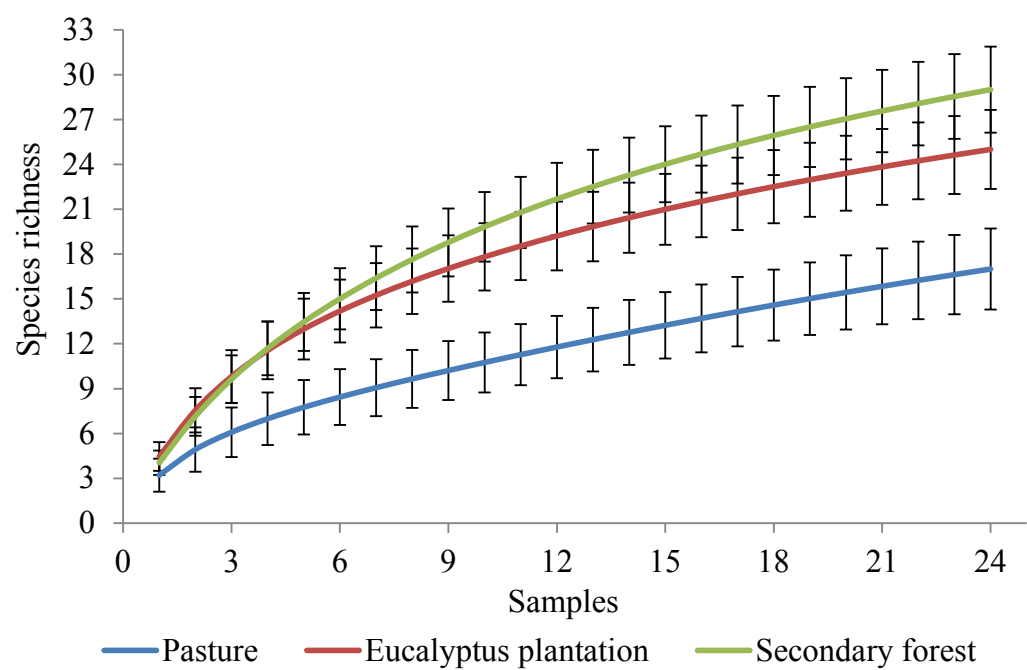

Figure 1. Species accumulation curves (Mao Tau method) with 95\% confidence interval for the ant fauna collected in different land-use systems, in the municipality of Sapucaia, Rio de Janeiro, Brazil

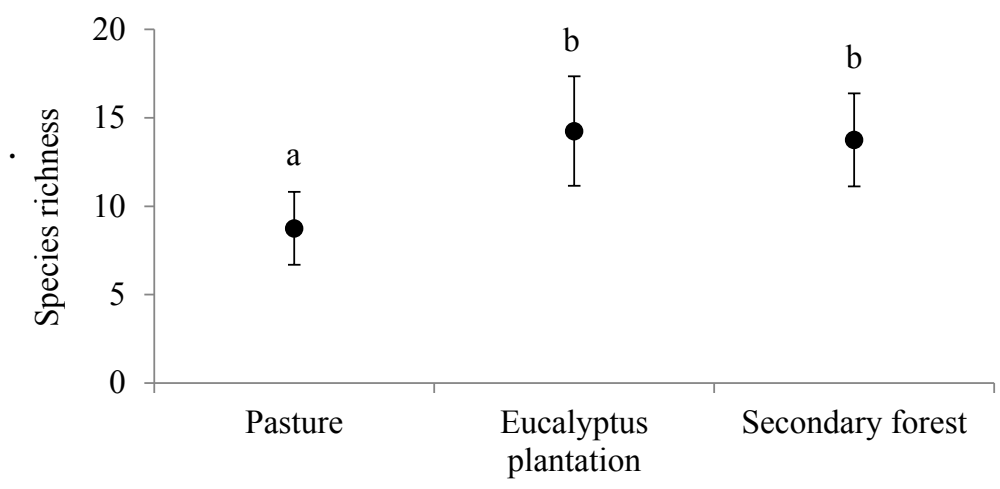

Land-use systems

Figure 2. Average species richness ( \pm Standard Deviation) for the ant fauna collected in different land-use systems in the municipality of Sapucaia, Rio de Janeiro, Brazil. Different letters indicate significant difference between the land-use systems $(p \leq 0.05)$.
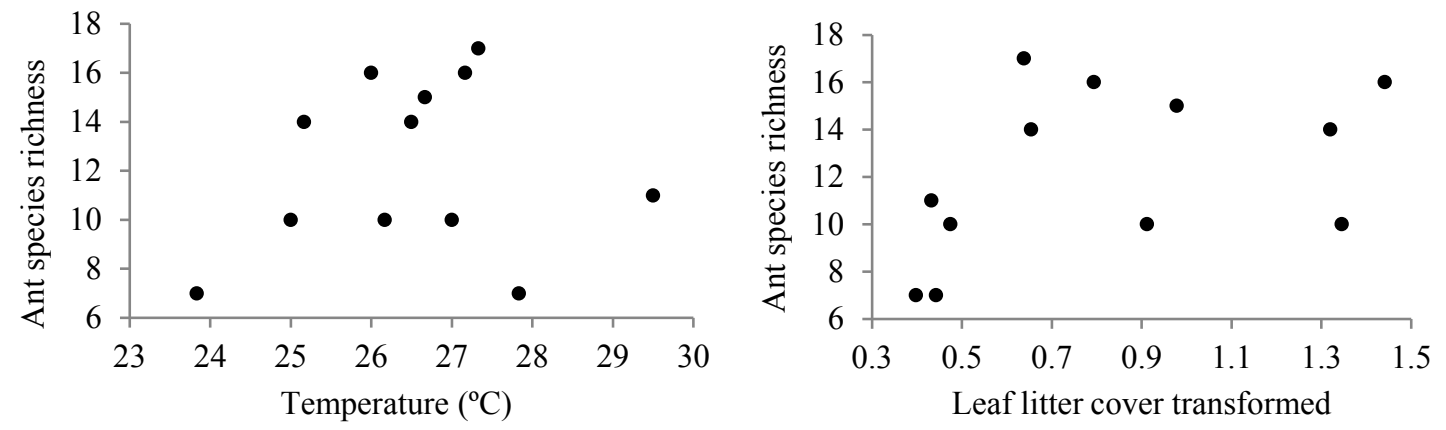

Figure 3. Relationship between ant species richness and temperature $\left(\mathrm{F}_{1,12}=2.59 ; p=0.15\right)$ and leaf litter cover $\left(\mathrm{F}_{1,12}=0.80 ; p=0.40\right)$ in different land-use systems in the municipality of Sapucaia, Rio de Janeiro, Brazil. 


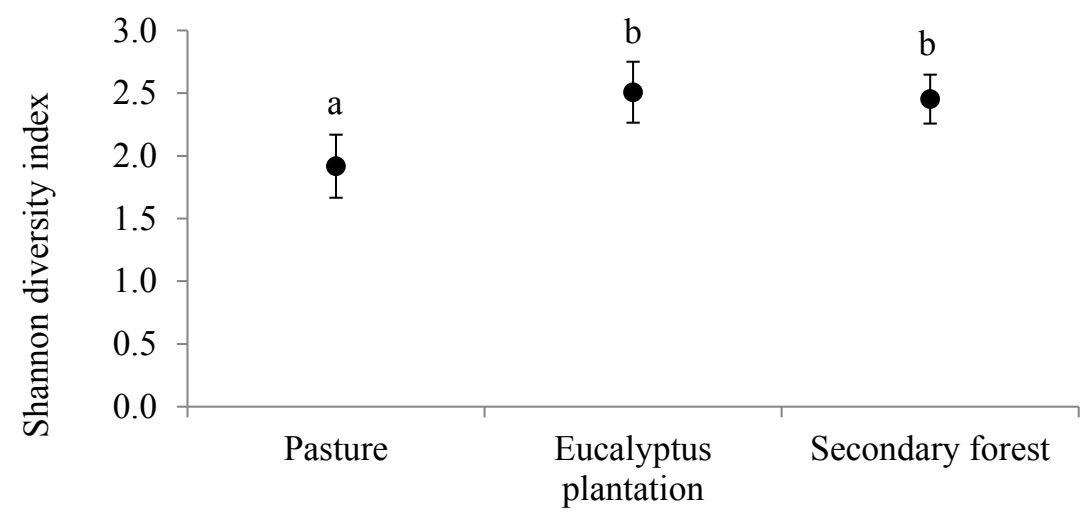

Land-use systems

Figure 4. Average Shannon diversity index ( \pm Standard Deviation) for the ant fauna collected in different land-use systems in the municipality of Sapucaia, Rio de Janeiro, Brazil. Different letters indicate significant difference between the land-use systems $(p \leq 0.05)$.
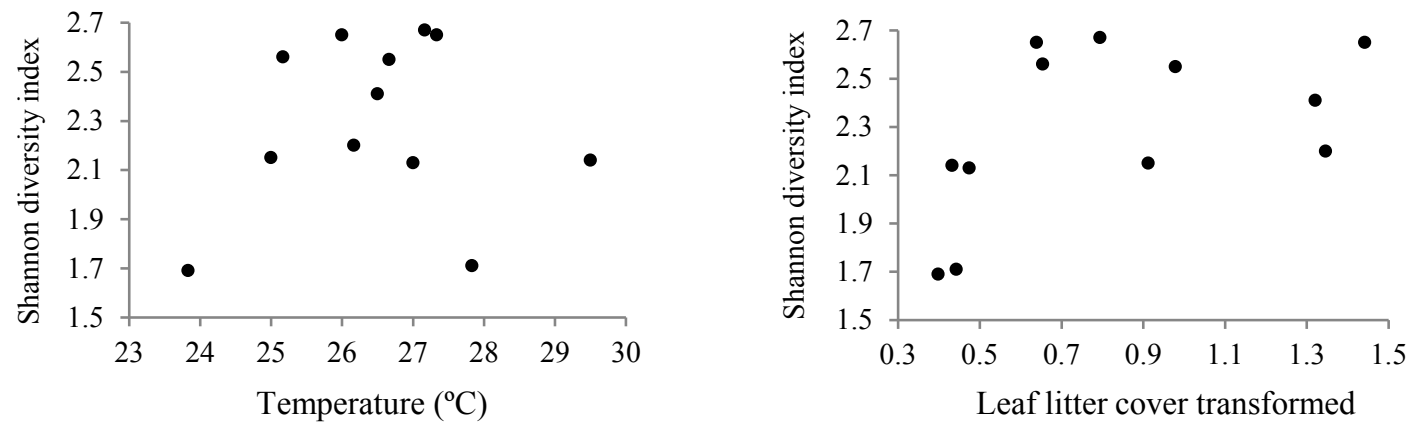

Figure 5. Relationship between Shannon diversity index for the ant fauna and temperature $\left(\mathrm{F}_{1,12}=2.84 ; p=0.14\right)$ and leaf litter cover $\left(\mathrm{F}_{1,12}=0.44 ; p=0.53\right)$ in different land-use systems in the municipality of Sapucaia, Rio de Janeiro, Brazil.

Eight species were found exclusively in the pasture, seven in the eucalyptus plantation and 14 species occurred exclusively in the secondary forest. Only six species occurred in all land-use systems. There was a significant difference in ant species composition between environments (Anosim; $\mathrm{R}=0.93 ; p<0.01$; Figure 6). The pairwise comparison detected significant differences between pasture and eucalyptus plantation (Anosim; $\mathrm{R}=0.95 ; p=0.03$ ), pasture and secondary forest (Anosim; $\mathrm{R}=1.00 ; p<0.03$ ), and eucalyptus plantation and secondary forest (Anosim; $\mathrm{R}=0.99$; $p<0.03$ ). Higher air temperatures were mainly related to the ant fauna composition in the pasture. On the other hand, higher values of leaf litter cover are mainly related to the ant community of the secondary forest.
The ant guilds with the largest number of species were litter omnivores and scavengers (13 species), followed by soil or litter dominant true omnivorous (10 species), and fungus-growers (8 species) (Table 1 ). In the pasture and secondary forest, we found seven guilds, whereas in the eucalyptus plantation we collected species of six guilds (Table 3 ). The frequency of ant species richness per guilds in the pasture differed significantly from those observed in the eucalyptus plantation $\left(\chi^{2}=25.406 ; p<0.01\right)$ and secondary forest $\left(\chi^{2}=28.76 ; p<0.01\right)$. In contrast, the frequency of ant species richness per guilds in the eucalyptus plantation and secondary forest did not differ significantly $\left(\chi^{2}=6.633 ; p=0.36\right)$. 


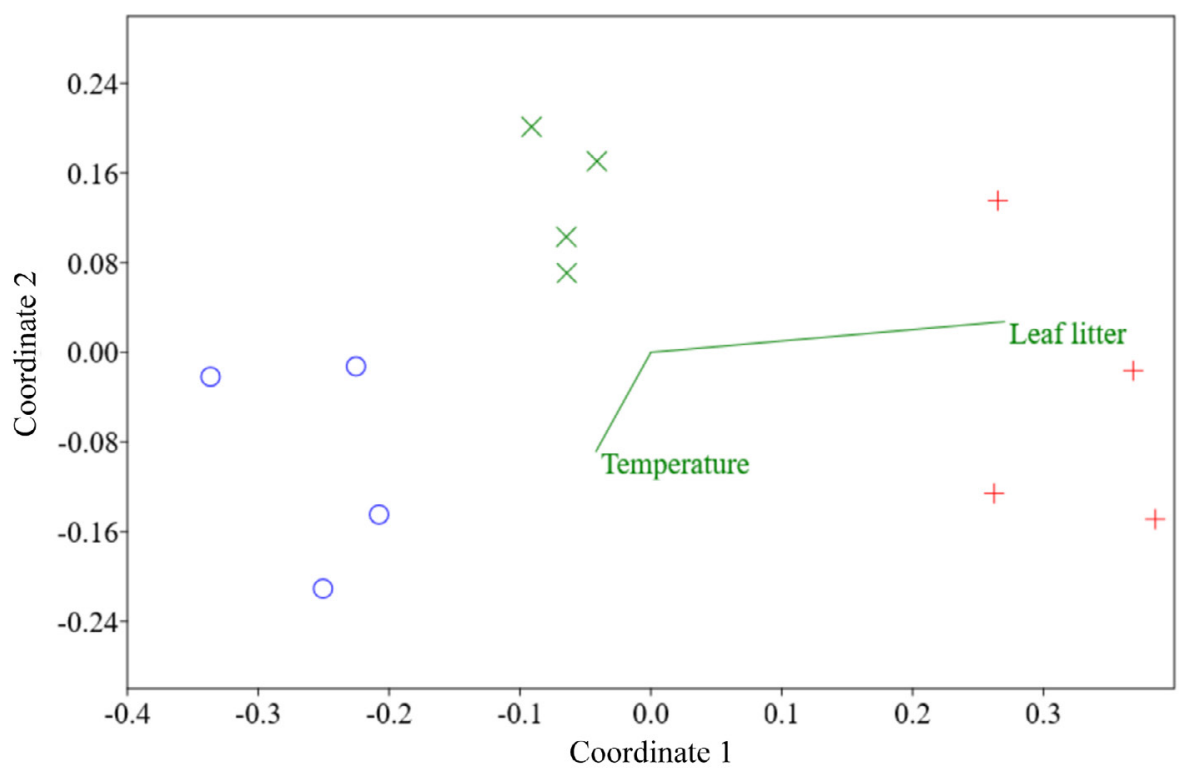

Figure 6. Non-metric multidimensional scaling ordination (NMDS) for ants collected in pasture (O), eucalyptus plantation $(x)$ and secondary forest $(+)$, in the municipality of Sapucaia, Rio de Janeiro, Brazil, with Jaccard's similarity index (Stress $=0.075)$.

Table 3. Percentage of the number of species in each guild in different land-use systems in the municipality of Sapucaia, Rio de Janeiro, Brazil.

\begin{tabular}{lcccc}
\multicolumn{1}{c}{ Guilds } & Pasture & Eucalyptus plantation & Secondary forest & Total \\
\hline Arboreal omnivorous & 11.8 & 0.0 & 0.0 & 4.3 \\
\hline Leafcutters & 5.9 & 12.0 & 17.2 & 17.0 \\
\hline Fungus-growers & 11.8 & 4.0 & 3.4 & 4.3 \\
\hline Soil or litter dominants & 11.8 & 16.0 & 17.2 & 12.8 \\
\hline Soil or litter dominant true omnivorous & 17.6 & 28.0 & 24.1 & 21.3 \\
\hline Litter omnivores and scavengers & 29.4 & 36.0 & 27.6 & 27.7 \\
\hline Soil cryptic predators & 0.0 & 0.0 & 3.4 & 2.1 \\
\hline Litter generalist predators & 11.8 & 4.0 & 6.9 & 10.6
\end{tabular}

\section{DISCUSSION}

Native tropical forests usually present higher ant species richness and diversity when compared to pastures and eucalyptus plantations (Gomes et al., 2013; Martins et al., 2011; Soares et al., 2010). However, this pattern was not completely corroborated by the present study. In general, tropical forests have several vertical strata and higher species richness of plants than pastures and eucalyptus plantations, and so they have higher structural complexity (Gomes et al., 2013; Martins et al., 2011). In addition, high plant diversity creates a heterogeneous leaf litter, which provides a greater diversity of sites for nesting and food for ants (Pereira et al., 2007). This explains the lower ant species richness and diversity in the pasture. On the other hand, the studied eucalyptus plantation has structural complexity similar to the secondary forest, due to the presence of a native understory and a thick layer of leaf litter. This structure provides a considerable number of niches and ant species richness and diversity, similar to the native forest in regeneration. Consonant results were observed in other studies (Braga et al., 2010; Cantarelli et al., 2015; Marinho et al., 2002). 
The use of other collection techniques and sampling in different vertical strata could provide the collection of more species of ants (Montine et al., 2014). Although the sampling effort was not enough to collect all ant species of the land-use systems, it is a common pattern in tropical ecosystems for the ant fauna and is related to the aggregated spatial distribution pattern of the species, the high diversity of the family Formicidae and the presence of rare species (Santos et al., 2006).

Despite the similarities in the structural complexity, the different conditions of each environment regarding biotic and abiotic factors were determinants for the structuring of the ant communities in the land-use systems. Some ant species present limitations to colonize simplified environments due to several factors, to include lack of food, nesting resources, abiotic conditions specificity and limited competition abilities (Martins et al., 2011). In contrast, invasive and generalist ant species with low ecological requirements may present greater competitive success in habitats with less structural complexity (Martins et al., 2011). In the present study the most frequent species in the pasture - Ectatomma edentatum Roger, 1863, Camponotus rufipes Fabricius, 1775 and Wasmannia auropunctata (Roger, 1863) are common in anthropized habitats (Almeida et al., 2007; Coriolano et al., 2014; Estrada et al., 2014; Iop et al., 2009). In addition, W. auropunctata is an invasive and generalist species with high reproductive and predatory capacity (Delabie, 1988). Atta sexdens rubropilosa Forel, 1908 was the most abundant in the eucalyptus plantation for using the leaves of this species for the cultivation of the fungus from which it feeds, being considered important pest of this tree (Zanetti et al., 2014). In the secondary forest, the most abundant species, Odontomachus chelifer Latreille, 1802, is a predator and an important seed disperser, being commonly collected in semi-deciduous seasonal forests, and rarely observed in highly anthropized habitats (Almeida et al., 2013). Ectatomma permagnum Forel, 1908 has already been collected in eucalyptus plantations and native forests (Soares et al., 2010).

One species that deserves attention is Tranopelta gilva Mayr, 1866, which is not commonly found in studies carried out in areas under the Atlantic Forest domain, maybe because it is not easily observed foraging on the surface (Baccaro et al., 2015). There is scarce information about the biology of species of this genus, but it is known that they build their nests in the soil or leaf litter under barks of tree trunks in forests (Baccaro et al., 2015).

The number of ant guilds may be positively related to the complexity of the vegetative structure (Macedo et al., 2011), but this finding was not observed in this work since the pasture and the secondary forest presented the same number of guilds. On the other hand, the frequency of species richness in the guilds was influenced by the land-use systems. The vegetation structure of the native forest and the commercial forest provided guilds of ants with a relative number of ant species different from the pasture. This result reinforces the usefulness of ant guilds as indicators of environmental quality. It is worth mentioning that Cephalotes pusillus (Klug, 1824) and Crematogaster sp.1, the only species classified in the guild as "arboreal omnivorous", were only recorded in the pasture. This fact could be due to the presence of trees and shrubs in the one studied. It is very likely that there are also arboreal ants in the eucalyptus plantation and secondary forest; however, the method used in this study aimed to sample epigeic ants and therefore did not allow the detection of arboreal ants.

\section{CONCLUSIONS}

The present study showed that ant communities could be used to assess the effects of land-use changes by providing subsidies for the use of ants as environmental indicators. In addition, it emphasizes the need for conservation of natural forests for protection of the biodiversity of Atlantic Forest. Even the secondary forest at an intermediate ecological succession stage can show a diverse fauna different from that of adjacent anthropized areas. However, our results also indicate that areas cultivated with forest species that allow a good development of an understory with native species can harbor considerable ant diversity.

\section{ACKNOWLEDGEMENTS}

The authors are thankful to UFRRJ for a research fellowship granted to Laiz da Cunha Messias Honório Apolinário. 


\section{SUBMISSION STATUS}

Received: 16 Nov., 2017

Accepted: 13 Dec., 2018

\section{CORRESPONDENCE TO}

\section{Fábio Souto Almeida}

Universidade Federal Rural do Rio de Janeiro (UFRRJ), Av. Prefeito Alberto Lavinas, 1847, CEP 25802-100, Três Rios, RJ, Brasil

e-mail: fbio_almeida@yahoo.com.br

\section{REFERENCES}

Agosti D, Majer JD, Alonso LE, Schultz TR. Ants: standard methods for measuring and monitoring biodiversity. Washington, DC: Smithsonian Institution Press; 2000.

Almeida FS, Mayhe-Nunes AJ, Queiroz JM. The importance of poneromorph ants for seed dispersal in altered environments. Sociobiology 2013; 60(3): 229-235. 10.13102/sociobiology.v60i3.229-235

Almeida FS, Queiroz JM, Mayhé-Nunes AJ. Distribuição e abundância de ninhos de Solenopsis invicta Buren (Hymenoptera: Formicidae) em um agroecossistema diversificado sob manejo orgânico. Floresta e Ambiente 2007 [cited 2019 May 21]; 14(1): 34-44. Available from: http://bit.ly/2VSUtRx

Baccaro FB, Feitosa RM, Fernandes F, Fernandes IO, Izzo TJ, Souza JLP et al. Guia para os gêneros de formigas do Brasil. Manaus: Instituto Nacional de Pesquisas da Amazônia; 2015.

Boscardin J, Costa EC, Delabie JHC. Relação entre guildas de formigas e a qualidade ambiental em Eucalyptus grandis submetido a diferentes controles de plantas infestantes no sul do Brasil. Entomotropica 2014 [cited 2019 May 21]; 29(3): 173-182. Available from: http://bit.ly/2Wl40Ac

Braga DL, Louzada JNC, Zanetti R, Delabie J. Avaliação rápida da diversidade de formigas em sistemas de uso do solo no sul da Bahia. Neotropical Entomology 2010; 39(4): 464-469. 10.1590/S1519-566X2010000400002

Brasil. Ministério do Meio Ambiente. Mapas de cobertura vegetal dos biomas brasileiros. 2007 [cited 2016 May 20]. Available from: https://bit.ly/1aLx8EQ

Cantarelli EB, Fleck MD, Granzotto F, Corassa JN, Avila M. Diversidade de formigas (Hymenoptera: Formicidae) da serapilheira em diferentes sistemas de uso do solo. Ciência Florestal 2015; 25(3): 607-616. 10.5902/1980509819612

Conselho Nacional do Meio Ambiente - Conama. Resolução Conama n. 6, de 4 de maio de 1994. Diário Oficial da República Federativa do Brasil, Brasília (1994
May 30) [cited 2019 May 21]; Sec. 1: 7913-7914. Available from: http://bit.ly/2VTfj3b

Coriolano RE, Estrada MA, Santos NT, Caixeiro LR, Vargas AB, Almeida FS. Mirmecofauna associada à arborização urbana no município de Três Rios, RJ, Brasil. Revista Brasileira de Biociências 2014 [cited 2019 May 21]; 12(4): 210-214. Available from: http:// bit.ly/2MeeUUX

DaRocha WD, Neves FS, Dáttilo W, Delabie JHC. Epiphytic bromeliads as key components for maintenance of ant diversity and ant-bromeliad interactions in agroforestry system canopies. Forest Ecology and Management 2016; 372: 128-136. 10.1016/j.foreco.2016.04.011

Delabie JHC. Ocorrência de Wasmannia auropunctata (Roger, 1863) (Hymenoptera, Formicidae, Myrmicinae) em cacauais na Bahia, Brasil. Revista Theobroma 1988 [cited 2019 May 21]; 18(1): 29-37. Available from: http:// bit.ly/2wdu $1 \mathrm{mE}$

Delabie JHC, Agosti D, Nascimento IC. Litter ant commnunities of the Brazilian Atlantic rain forest region. In: Agosti D, Majer J, Alonso L, Schultz T, editors. Sampling ground-dwelling ants: case studies from the world' rain forests. Perth: School of Environmental Biology; 2000. p. 59-69.

Dias NS, Zanetti R, Santos MS, Louzada J, Delabie J. Interação de fragmentos florestais com agroecossistemas adjacentes de café e pastagem: respostas das comunidades de formigas (Hymenoptera, Formicidae). Iheringia: Série Zoologia 2008; 98(1): 136-142. 10.1590/S007347212008000100017

Estrada MA, Coriolano RE, Santos NT, Caixeiro LR, Vargas AB, Almeida FS. Influência de áreas verdes urbanas sobre a mirmecofauna. Floresta e Ambiente 2014; 21(2): 162-169. 10.4322/floram.2014.035

Gomes BK, Oliveira EF, Cunha WL. Padrões da diversidade de formigas no Parque das Aves (Apucarana-PR). Revista em Agronegócios e Meio Ambiente 2012 [cited 2019 May 21]; 5(3): 605-615. Available from: http://bit.ly/30D92ay

Gomes DS, Almeida FS, Vargas AB, Queiroz JM. Resposta da assembleia de formigas na interface solo-serapilheira a um gradiente de alteração ambiental. Iheringia: Série Zoologia 2013; 103(2): 104-109. 10.1590/S007347212013000200004

Groc S, Delabie JHC, Fernandez F, Leponce M, Orivel J, Silvestre R et al. Leaf-litter ant communities (Hymenoptera: Formicidae) in a pristine Guianese rainforest: stable functional structure versus high species turnover. Myrmecological News 2014 [cited 2019 May 21]; 19: 43-51. Available from: http://bit.ly/2Jz9Zf1

Hammer $\varnothing$, Harper DAT, Ryan PD. PAST: paleontological statistics software package for education and data analysis. Palaeontologia Electronica 2001 [cited 2019 May 21]; 4(1): 4. Available from: http://bit.ly/2LZmEKk 
Instituto Brasileiro de Geografia e Estatística - IBGE. Mapa de clima do Brasil [mapa]. Rio de Janeiro: IBGE; 2002 [cited 2016 Feb. 20]. Available from: http://bit. ly/2WfeYYi

Instituto Brasileiro de Geografia e Estatística - IBGE. Sapucaia. 2016 [cited 2016 Feb. 15]. Available from: http:// bit.ly/2VI7yYV

Instituto Estadual do Ambiente - Inea. Plano regional de saneamento com base municipalizada nas modalidades água, esgoto e drenagem urbana dos municípios de Areal, Carmo, São José do Vale do Rio Preto, Sapucaia, Sumidouro e Teresópolis. Rio de Janeiro; 2014 [cited 2016 Mar. 20]. Available from: http://bit.ly/2HsnNFI

Iop S, Caldart VM, Lutinski JA, Garcia FRM. Formigas urbanas da cidade de Xanxerê, Santa Catarina, Brasil. Revista Biotemas 2009; 22(2): 55-64. 10.5007/2175-7925.2009v22n2p55

Joly CA, Metzger JP, Tabarelli M. Experiences from the Brazilian Atlantic Forest: ecological findings and conservation initiatives. New Phytologist 2014; 204(3): 459-473. 10.1111/nph.12989

Kwon TS, Lee CM, Sung JH. Diversity decrease of ant (Formicidae, Hymenoptera) after a forest disturbance: different responses among functional guilds. Zoological Studies 2014; 53: 37-47. 10.1186/s40555-014-0037-Z

Macedo LPM, Berti Filho E, Delabie JHC. Epigean ant communities in Atlantic Forest remnants of São Paulo: a comparative study using the guild concept. Revista Brasileira de Entomologia 2011; 55(1): 75-78. 10.1590/ S0085-56262011000100012

Marinho CGS, Zanetti R, Delabie JHC, Schlindwein MN, Ramos LS. Diversidade de formigas (Hymenoptera: Formicidae) da serapilheira em eucaliptais (Myrtaceae) e área de cerrado de Minas Gerais. Neotropical Entomology 2002; 31(2): 187-195. 10.1590/S1519566X2002000200004

Martins L, Almeida FS, Mayhé-Nunes AJ, Vargas AB. Efeito da complexidade estrutural do ambiente sobre as comunidades de formigas (Hymenoptera: Formicidae) no município de Resende, RJ, Brasil. Revista Brasileira de Biociências 2011 [cited 2019 May 21]; 9(2): 174-179. Available from: http://bit.ly/2YFpPIs

Montine PSM, Viana NF, Almeida FS, Dattilo W, Santanna AS, Martins L et al. Seasonality of epigaeic ant communities in a Brazilian Atlantic rainforest. Sociobiology 2014; 61(2): 178-183. 10.13102/sociobiology.v61i2.178-183

Myers N, Mittermeier RA, Mittermeier CG, Fonseca GAB, Kent J. Biodiversity hotspots for conservation priorities. Nature 2000 [cited 2019 May 21]; 403: 853-845. Available from: https://go.nature.com/2VFf8DJ

Napoleão JBP. O estado do ambiente: indicadores ambientais do Rio de Janeiro. Rio de Janeiro: Instituto Estadual do Ambiente; 2011.
Oliveira MA, Gomes CFF, Pires EM, Marinho CGS, Lucia TMCD. Bioindicadores ambientais: insetos como um instrumento desta avaliação. Revista Ceres 2014; 61(Suppl.): 800-807. 10.1590/0034-737x201461000005

Pereira LPC, Almeida FS, Vargas AB, Araújo MS, MayhéNunes AJ, Queiroz JM. Seasonal analysis of taxonomic and functional diversity of poneromorph ant assemblages in the Amazon Forest. Sociobiology 2016; 63(3): 941-949. 10.13102/sociobiology.v63i3.1053

Pereira MPS, Queiroz JM, Valcarcel R, Mayhé-Nunes AJ. Fauna de formigas como ferramenta para monitoramento de áreas de mineração reabilitada na Ilha da Madeira, Itaguaí, Rio de Janeiro. Ciência Florestal 2007; 17(3): 197-204. 10.5902/198050981951

Ribas CR, Campos RBF, Schmidt FA, Solar RRC. Ants as indicators in Brazil: a review with suggestions to improve the use of ants in environmental monitoring programs. Psyche 2012; 2012: 636749. 10.1155/2012/636749

Ribeiro MC, Martensen AC, Metzger JP, Tabarelli M, Scarano F, Fortin MJ. The Brazilian Atlantic Forest: a shrinking biodiversity hotspot. In: Zachos FE, Habel JC, editors. Biodiversity hotspots: distribution and protection of conservation priority areas. Heidelberg: Springer; 2011. p. $405-434$.

Santos JRM, Mariano CSF, Martins LCB, Lacau LSR, Nascimento IC, Rocha WD et al. Assembleias de formigas epigeias (Hymenoptera: Formicidae) em um cacaual e remanescente de floresta da Amazônia Oriental, Brasil. Agrotrópica 2015; 27(2): 149-160. 10.21757/0103-3816.2015v27n2p149-160

Santos MS, Louzada JNC, Dias N, Zanetti R, Delabie JHC, Nascimento IC. Riqueza de formigas (Hymenoptera: Formicidae) da serapilheira em fragmentos de floresta semidecíduo da Mata Atlântica na região do Ato do Rio Grande, MG, Brasil. Iheringia: Série Zoologia 2006; 96(1): 95-101. 10.1590/S0073-47212006000100017

Silvério Neto R, Bento MC, Menezes SJMC, Almeida FS. Caracterização da cobertura florestal de unidades de conservação da Mata Atlântica. Floresta e Ambiente 2015; 22(1): 32-41. 10.1590/2179-8087.058013

Silvestre R, Silva RR. Guildas de formigas da Estação Ecológica Jataí, Luiz Antônio - SP: sugestões para aplicação do modelo de guildas como bio-indicadores ambientais. Biotemas 2001; 14(1): 37-69. 10.5007/\%25x

Soares SA, Antonialli WF Jr, Lima SE Jr. Diversidade de formigas epigéicas (Hymenoptera, Formicidae) em dois ambientes no Centro-Oeste do Brasil. Revista Brasileira de Entomologia 2010; 54(1): 76-81. 10.1590/S008556262010000100009

Zanetti R, Zanuncio JC, Santos JC, Silva WLP, Ribeiro GT, Lemes PG. An overview of integrated management of leaf-cutting ants (Hymenoptera: Formicidae) in Brazilian Forest plantations. Forests 2014; 5(3): 439-454. 10.3390/ f5030439 